University of Nebraska - Lincoln

DigitalCommons@University of Nebraska - Lincoln

Agronomy \& Horticulture -- Faculty Publications

Agronomy and Horticulture Department

2017

\title{
Genetic diversity of Danthonia spicata (L.) Beauv. based on genomic simple sequence repeat markers
}

\author{
Chandra S. Thammina \\ USDA-ARS \\ Keenan Amundsen \\ University of Nebraska-Lincoln, kamundsen2@unl.edu \\ Shaun B. Bushman \\ Utah State University, shaun.bushman@ars.usda.gov \\ Matthew H. Kramer \\ USDA-ARS, matt.kramer@ars.usda.gov \\ Scott E. Warnke \\ USDA-ARS, Scott.Warnke@ars.usda.gov
}

Follow this and additional works at: https://digitalcommons.unl.edu/agronomyfacpub

Part of the Agricultural Science Commons, Agriculture Commons, Agronomy and Crop Sciences Commons, Botany Commons, Horticulture Commons, Other Plant Sciences Commons, and the Plant Biology Commons

Thammina, Chandra S.; Amundsen, Keenan; Bushman, Shaun B.; Kramer, Matthew H.; and Warnke, Scott E., "Genetic diversity of Danthonia spicata (L.) Beauv. based on genomic simple sequence repeat markers" (2017). Agronomy \& Horticulture -- Faculty Publications. 1050.

https://digitalcommons.unl.edu/agronomyfacpub/1050

This Article is brought to you for free and open access by the Agronomy and Horticulture Department at DigitalCommons@University of Nebraska - Lincoln. It has been accepted for inclusion in Agronomy \& Horticulture -Faculty Publications by an authorized administrator of DigitalCommons@University of Nebraska - Lincoln. 


\title{
Genetic diversity of Danthonia spicata (L.) Beauv. based on genomic simple sequence repeat markers
}

\author{
Chandra S. Thammina - Keenan Amundsen - Shaun B. Bushman • \\ Matthew Kramer · Scott E. Warnke
}

Received: 2 August 2017 / Accepted: 29 November 2017

(C) Springer Science+Business Media B.V., part of Springer Nature (outside the USA) 2017

\begin{abstract}
Danthonia spicata (L.) Beauv., commonly known as poverty oatgrass, is a perennial bunch-type grass native to North America. D. spicata is often found in low input turfgrass areas on the East Coast of the United States and has potential for development as a new native low input turfgrass species. Roche 454 sequenced randomly sheared genomic DNA reads of D. spicata were mined for SSR markers using the MIcroSAtellite identification tool. A total of 66,553 singlet sequences (approximately $37.5 \mathrm{Mbp}$ ) were examined, and 3454 SSR markers were identified.
\end{abstract}

C. S. Thammina $\cdot$ S. E. Warnke $(\bowtie)$

Floral and Nursery Plants Research Unit, USDA-ARS, U.S. National Arboretum, 10300 Baltimore Avenue, Building 010A, Beltsville, MD 20705, USA

e-mail: Scott.Warnke@ars.usda.gov

C. S. Thammina

Department of Plant Biology and Pathology, Rutgers University, 59 Dudley Road, New Brunswick, NJ 08901, USA

\section{K. Amundsen}

Department of Agronomy and Horticulture, University of Nebraska, Lincoln, NE 68583, USA

\section{S. B. Bushman}

Forage and Range Research Lab, Utah State University, Logan, UT 84322, USA

\section{Kramer}

USDA-ARS, Statistics Group, 10300 Baltimore Avenue, Building 005, Beltsville, MD 20705, USA
Trinucleotide motifs with greater than six repeats and possessing unique PCR priming sites within the genome, as determined by Primer-BLAST, were evaluated visually for heterozygosity and mutation consistent with stepwise evolution using CLC Genomics software. Sixty-three candidate markers were selected for testing from the trinucleotide SSR marker sites meeting these in silico criteria. Ten primer pairs that amplified polymorphic loci in preliminary experiments were used to screen 91 individual plants composed of at least 3-5 plants from each of 23 different locations. The primer pairs amplified 54 alleles ranging in size from 71 to $246 \mathrm{bp}$. Minimum and maximum numbers of alleles per locus were two and 12 , respectively, with an average of 5.4. A dendrogram generated by unweighted pair group method with arithmetic mean cluster analysis using the Jaccard's similarity coefficient was in agreement with the grouping obtained by Structure v2.3. The analyses were dominated by clonal groupings and lack evidence for gene flow with some alleles present in a single plant from a single location. Fourteen multilocus genotype groups were observed providing strong evidence for asexual reproduction in the studied $D$. spicata populations.

Keywords Danthonia - Germplasm · Genetic diversity $\cdot$ Microsatellites $\cdot$ Poaceace $\cdot$ Polymorphism . Turfgrass 
Abbreviations

AFLP Amplified fragment length polymorphism

AMOVA Analysis of molecular variance

MISA MIcroSAtellite identification tool

MLGs Multilocus genotypes

NCBI National center for biotechnology information

RAPD Random amplified polymorphic DNA

SSR Simple sequence repeat

UPGMA Unweighted pair group method with arithmetic averaging

\section{Introduction}

The genus Danthonia (Poaceae) grows in a diversity of tropical, semi-tropical and temperate habitats. At present, there are nine species in South America, eight in North America, three in Europe, two in Africa, and two in Asia (Linder and Verboom 1996). It is a coolseason genus in the PACCAD clade more closely related to warm-season turf species (Grass Physiology Working Group 2001). The genus Danthonia has a base chromosome number of $x=6$ and in North America, seven of the eight species (D. californica Bol., D. compressa Austin, D. intermedia Vasey, D. parryi Scribn., D. sericea Nutt., D. spicata (L.) Beauv. and D. unispicata (Thurb.) Munro ex Macoun) are native while $D$. decumbens (L.) DC., is introduced from Europe (Darbyshire 2003). D. spicata L., (poverty oatgrass) is a native perennial, polyploid, $\mathrm{C}_{3}$ bunch grass that is widespread throughout the eastern and northern United States and southern Canada (Clay 1982). It is mainly present in impoverished or low-fertility soils and hence the name, "poverty oatgrass". It is a very shade tolerant, drought tolerant, low maintenance grass, frequently found on unimproved turf sites (Warnke 2010). However, it has some disadvantages with respect to cultivation such as poor seed yield, shattering of seed heads prior to harvest, and seed dormancy (Warnke 2010). D. spicata has potential as a low input turf species, however, a more complete understanding of its reproductive biology and genetic diversity is needed.

Danthonia spicata produces two types of seed heads terminal "chasmogamous" seed heads that have the potential for outcrossing yet often remain closed exhibiting no signs of allogamy and axial "cleistogamous" seed heads at the nodes of the flowering stem that never open and therefore have no potential for outcrossing. Weatherwax (1928) reported that both seed heads exhibit rudimentary lodicules, short styles with few stigma hairs and smallundeveloped anthers. Several papers have suggested that the dimorphic seed heads evolved due to a symbiotic relationship with the epiphytic fungus Atkinsonella hypoxylon (Clay 1984), that can produce a mass of fungal hyphe at the node of the flowering stem, refered to as "choke", and abort seed head production. Apomixis has also been suggested as a reproductive method in D. spicata (Philipson 1986) however no experimental evidence is available.

In the only study to evaluate $D$. spicata genetic diversity Clay and Antonovics (1985b) evaluated the variation of quantitative characters in chasmogamous $(\mathrm{CH})$ and cleistogamous (CL) progeny raised in their native habitat and in the greenhouse. Significant genetic variation existed for twelve quantitative characters measured in greenhouse-grown progeny. Two morphologically similar groups of families were identified and most of the genetic variation was between families with only $5 \%$ of the variation within families. In field-grown plants, variance component analysis suggested that CL progenies were genetically more similar to each other than were $\mathrm{CH}$ progenies from the same plant and that selective differentials would be larger among families than within families. The use of marker loci as a method of estimating outcrossing rates was suggested however no polymorphic marker loci could be identified.

DNA-based molecular markers like random amplified polymorphic DNA (RAPD), simple sequence repeat (SSR), and amplified fragment length polymorphism (AFLP) have been used in fields such as taxonomy, plant breeding, genetic engineering etc. (Chai and Sticklen 1998; Joshi et al. 2011). Among these markers; SSR markers are widely distributed across genomes, highly polymorphic, codominant, and can be used to reproducibly fingerprint organisms in different laboratories (Kalia et al. 2011; Powell et al. 1996; Thammina et al. 2014). SSR markers have been used to examine genetic diversity in bahiagrass, Paspalum notatum Flüggé (Cidade et al. 2008), bermudagrass, Cynodon dactylon (L.) Pers. (Wu et al. 2006), creeping bentgrass, Agrostis stolonifera L. (Kubik et al. 2009), Kentucky bluegrass, Poa pratensis L. (Honig et al. 2010), Paspalum L. (Cidade 
Table 1 List of D. spicata (L.) Beauv. germplasm, used for assessing molecular diversity with genomic simple sequence repeat (SSR) markers

\begin{tabular}{|c|c|c|}
\hline Plant ID & Abbreviated plant ID ${ }^{\mathrm{a}}$ & Collection site \\
\hline $\begin{array}{l}\text { B05-16-001, B05-16-002, B05-16-004, B05-16- } \\
005\end{array}$ & B051, B052, В054, В055 & $\begin{array}{l}\text { Beltsville Agricultural Research Center, } \\
\text { Beltsville, MD }\end{array}$ \\
\hline BRP1-2, BRP1-3, BRP1-4, BRP1-5 & $\begin{array}{l}\text { BRP12, BRP13, BRP14, } \\
\text { BRP15 }\end{array}$ & Blue Ridge Parkway, location 1 \\
\hline BRP2-1, BRP2-3, BRP2-4, BRP2-5 & $\begin{array}{l}\text { BRP21, BRP23, BRP24, } \\
\text { BRP25 }\end{array}$ & Blue Ridge Parkway, location 2 \\
\hline BRP3-2, BRP3-3, BRP3-4, BRP3-5 & $\begin{array}{l}\text { BRP32, BRP33, BRP34, } \\
\text { BRP35 }\end{array}$ & Blue Ridge Parkway, location 3 \\
\hline BRP4-1, BRP4-3, BRP4-4, BRP4-5 & $\begin{array}{l}\text { BRP41, BRP43, BRP44, } \\
\text { BRP45 }\end{array}$ & Blue Ridge Parkway, location 4 \\
\hline BRP5-1, BRP5-2, BRP5-3, BRP5-4, BRP5-5 & $\begin{array}{l}\text { BRP51, BRP52, BRP53, } \\
\text { BRP54, BRP55 }\end{array}$ & Blue Ridge Parkway, location 5 \\
\hline BRP6-1, BRP6-2, BRP6-3, BRP6-4 & $\begin{array}{l}\text { BRP61, BRP62, BRP63, } \\
\text { BRP64 }\end{array}$ & Blue Ridge Parkway, location 6 \\
\hline CR-16-002, CR-16-003, CR-16-004, CR-16-005 & $\begin{array}{l}\text { CR162, CR163, CR164, } \\
\text { CR165 }\end{array}$ & Crossroads Cemetery, Carroll County, MD \\
\hline $\begin{array}{l}\text { EGCAP10-001, EGCAP10-002, EGCAP10-003, } \\
\text { EGCAP10-004 }\end{array}$ & CAP1, CAP2, CAP3, CAP4 & $\begin{array}{l}\text { United States National Arboretum, } \\
\text { Washington D.C. }\end{array}$ \\
\hline $\begin{array}{l}\text { EGFES10-001, EGFES10-002, EGFES10-003, } \\
\text { EGFES10-004 }\end{array}$ & FES1, FES2, FES3, FES4 & $\begin{array}{l}\text { United States National Arboretum, } \\
\text { Washington D.C. }\end{array}$ \\
\hline $\begin{array}{l}\text { EGMDT10-002, EGMDT10-003, EGMDT10-004, } \\
\text { EGMDT10-004 c1 }\end{array}$ & $\begin{array}{l}\text { MDT2, MDT3, MDT4, } \\
\text { MDT4 c1 }\end{array}$ & $\begin{array}{l}\text { United States National Arboretum, } \\
\text { Washington D.C. }\end{array}$ \\
\hline $\begin{array}{l}\text { EGMTH10-001, EGMTH10-002, EGMTH10-003, } \\
\text { EGMTH10-004 }\end{array}$ & $\begin{array}{l}\text { MTH1, MTH2, MTH3, } \\
\text { MTH4 }\end{array}$ & $\begin{array}{l}\text { United States National Arboretum, } \\
\text { Washington D.C. }\end{array}$ \\
\hline $\begin{array}{l}\text { EGMTO10-001, EGMTO10-002, EGMTO10-003, } \\
\text { EGMTO10-004 }\end{array}$ & $\begin{array}{l}\text { MTO1, MTO2, MTO3, } \\
\text { MTO4 }\end{array}$ & $\begin{array}{l}\text { United States National Arboretum, } \\
\text { Washington D.C. }\end{array}$ \\
\hline $\begin{array}{l}\text { EGSTR10-001, EGSTR10-003, EGSTR10-005, } \\
\text { EGSTR10-008 }\end{array}$ & STR1, STR3, STR5, STR8 & $\begin{array}{l}\text { United States National Arboretum, } \\
\text { Washington D.C. }\end{array}$ \\
\hline GW1-1, GW1-2, GW1-4 & GW11, GW12, GW14 & $\begin{array}{l}\text { George Washington and Jefferson National } \\
\text { Forest, Location } 1\end{array}$ \\
\hline KM-16-002, KM-16-003, KM-16-004, KM-16-005 & $\begin{array}{l}\text { KM162, KM163, KM164, } \\
\text { KM165 }\end{array}$ & Klees Mill Road, Carroll County, MD \\
\hline SK1-2, SK1-3, SK1-4, SK1-5 & SK12, SK13, SK14, SK15 & Skyline Drive, location 1 \\
\hline SK2-1, SK2-2, SK2-4, SK2-5 & SK21, SK22, SK24, SK25 & Skyline Drive, location 2 \\
\hline SK3-1, SK3-2, SK3-3, SK3-5 & SK31, SK32, SK33, SK35 & Skyline Drive, location 3 \\
\hline SK4-1, SK4-2, SK4-4, SK4-5 & SK41, SK42, SK44, SK45 & Skyline Drive, location 4 \\
\hline SK5-1, SK5-2, SK5-3, SK5-5 & SK51, SK52, SK53, SK55 & Skyline Drive, location 5 \\
\hline SK6-1, SK6-2, SK6-3, SK6-4 & SK61, SK62, SK63, SK64 & Skyline Drive, location 6 \\
\hline WH-16-002, WH-16-003, WH-16-005 & WH162, WH163, WH165 & White House, Beltsville, MD \\
\hline
\end{tabular}

B05 Beltsville agricultural research center; BRP blue ridge parkway; $C A P$ capitol columns; $C R$ Crossroads Cemetary; FES Fescue Varietal Trial; $G W$ George Washington and Jefferson National Forest; MDT Maryland Turf Center; MTH Mount Hamilton; MTO Mount Olivet; STR Grove of State Trees; KM Klees Mill Road; SK Skyline Drive; WH White House

${ }^{a}$ Abbreviated plant ID's were used as plant labels in Figs. 1, 2A-C

et al. 2013), zoysia grass, Zoysia spp. (Guo et al. 2012). The objectives of this study were to (a) utilize Roche 454 sequencing data from genomic DNA of $D$. spicata to develop SSR primer pairs and (b) utilize the SSR primer pairs to assess the levels of variability within and among native Danthonia populations. 


\section{Materials and methods}

Plant materials

Ninety-one individual D. spicata genotypes composed of 3-5 plants from each of 23 different locations in Maryland, North Carolina, Virginia, and Washington, D.C. were collected between spring 2010 and spring 2016 (Table 1). These collection sites were chosen randomly from the natural populations of D. spicata. The United States National Arboretum collection sites were all distinct populations located within the 182.1 ha that make up the facility. The Beltsville, MD sites are approximately a half-mile from each other and $24.1 \mathrm{~km}$ from the Arboretum. The Carroll County, MD locations are approximately $8.04 \mathrm{~km}$ apart and $80.4 \mathrm{~km}$ from the Arboretum and Beltsville. The Skyline drive collections were made by starting at the northern entrance to Shenandoah National Park in Front Royal, VA and collecting at picnic sites approximately $32.2 \mathrm{~km}$ apart throughout the Park. Blue Ridge Parkway collections were also collected at picnic sites from the northern end of the Parkway through approximately $64.4 \mathrm{~km}$ into North Carolina. Plants were maintained in a greenhouse in 4-inch clay pots containing PRO-MIX ${ }^{\circledR}$ HP MYCORRHIZAE ${ }^{\text {TM }}$ (Premier Horticulture Inc; Quakertown, PA, USA) at the Beltsville Agricultural Research Center, Beltsville, MD. Plants were maintained at a day temperature of $13-19{ }^{\circ} \mathrm{C}$ and night temperature of $17-23{ }^{\circ} \mathrm{C}$ under natural light. Peters Professional ${ }^{\circledR}$ Acid Special 21-7-7 fertilizer (Scotts Company LLC; Oxford, PA, USA) was applied every 30 days and irrigated as required. Genomic DNA was extracted from fresh young leaf tissue of D. spicata genotype using a PowerPlant ${ }^{\circledR}$ Pro DNA Isolation Kit (Mo Bio Laboratories, Inc., Carlsbad, CA, USA) according to the manufacturer's recommendations, and quantified with a NanoDrop 1000 Spectrophotometer (Thermo Fisher Scientific, Wilmington, DE, USA).

Genomic sequencing and primer design

Total genomic DNA was extracted from fresh leaf tissue of a D. spicata genotype at the United States National Arboretum (USNA, Washington, D.C., USA) and quantified using the aforementioned
Fig. 1 Dendrogram of 91 D. spicata (L.) Beauv. genotypes based on 10 simple sequence repeat (SSR) markers generated by unweighted pair group method with arithmetic averaging cluster analysis. Confidence levels greater or equal to $95 \%$ from bootstrap analysis (20,000 replicates) are indicated at the nodes

procedure. Genomic library construction and sequencing were performed at the Roy J. Carver Biotechnology Center, University of Illinois at UrbanaChampaign on a Roche 454 sequencer (Roche Diagnostics, Branford, CT, USA); (Tamaki et al. 2011). Later, singlet sequences were mined for SSR markers using the MIcroSAtellite identification tool (MISA) (Coello Coello and Cortés 2005) to detect tandem repeats of two to six nucleotides for at least five perfect repeat core motifs. Trinucleotide motifs with greater than six repeats and possessing unique polymerase chain reaction (PCR) priming sites within the genome, as determined by Primer-BLAST (Ye et al. 2012), were evaluated visually for heterozygosity and mutation consistent with stepwise evolution using CLC Genomics software. From the trinucleotide SSR sites meeting this in silico criteria, 63 candidate markers were selected for gradient-PCR tests. PCR primer pairs were designed with the following settings: primer length of $20 \pm 2$ nucleotides, GC content of $40-60 \%$, and a PCR product size ranging from 70 to $300 \mathrm{bp}$. PCR primers were manufactured by Integrated DNA Technologies (Coralville, Iowa, USA). The forward primers had an additional M13 (-21) universal sequence (TGTAAAACGACGGCCAGT) attached to the $5^{\prime}$ end to allow indirect fluorescent labeling of PCR products using just one universal FAM (6-carboxy-fluorescine)-labeled M13 primer (Schuelke 2000). These tests were conducted on EGFES10-002 and BRP2-3 clones, which were chosen randomly from the collected genotypes. PCR was carried out in a Bio-Rad T100 ${ }^{\mathrm{TM}}$ Thermal Cycler (BioRad Laboratories, Inc., Hercules, CA, USA). The $20-\mu \mathrm{L}$ PCR reaction mixture contained $20 \mathrm{ng}$ of template genomic DNA, $0.25 \mu \mathrm{M}$ of each reverse and universal FAM-labeled M13 (-21) primer, and $0.0625 \mu \mathrm{M}$ of the forward primer with $1 \times$ Bioline MangoMix and $2.5 \mathrm{mM}$ Bioline $\mathrm{MgCl} 2$ (Bioline, Taunton, MA, USA). PCR profiles consisted of initial denaturation at $94{ }^{\circ} \mathrm{C}$ for $5 \mathrm{~min}$; followed by 35 cycles of $94{ }^{\circ} \mathrm{C}$ for $30 \mathrm{~s}, 58-63{ }^{\circ} \mathrm{C}$ annealing temperature range for each primer pair for $45 \mathrm{~s}$, and $72{ }^{\circ} \mathrm{C}$ for $45 \mathrm{~s}$; followed by 8 cycles of $94{ }^{\circ} \mathrm{C}$ for $30 \mathrm{~s}, 53{ }^{\circ} \mathrm{C}$ for $45 \mathrm{~s}$, 


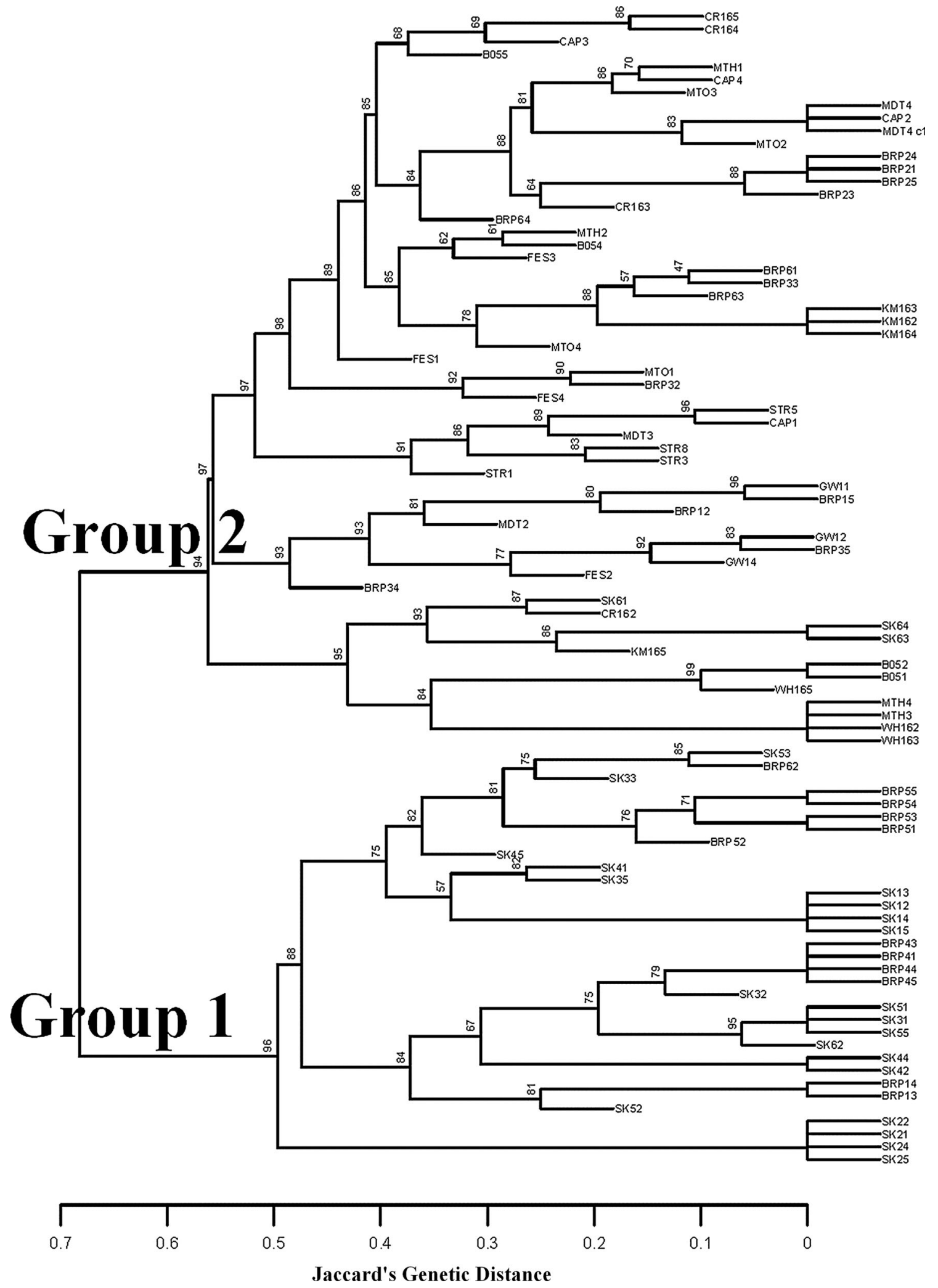



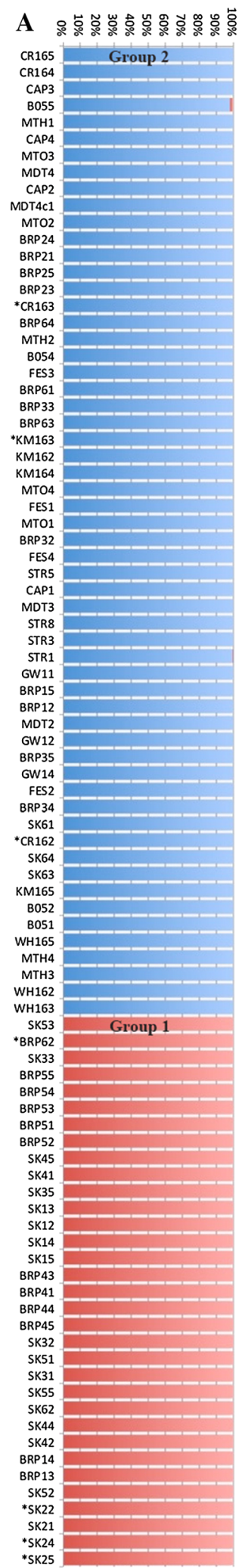

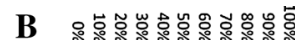

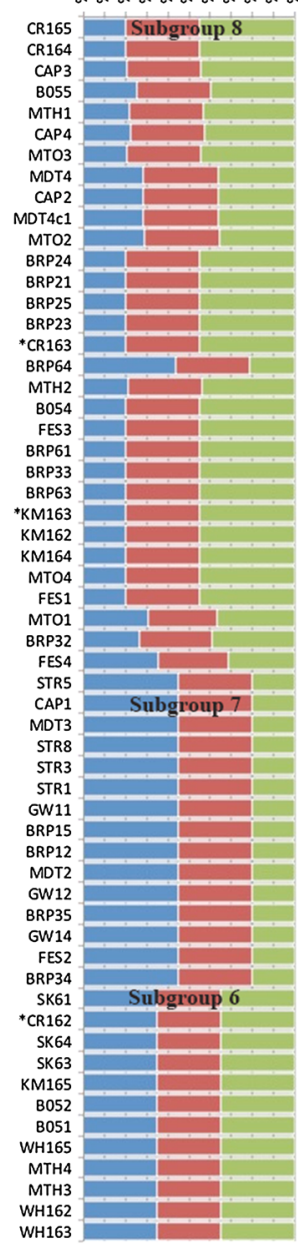

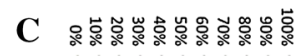

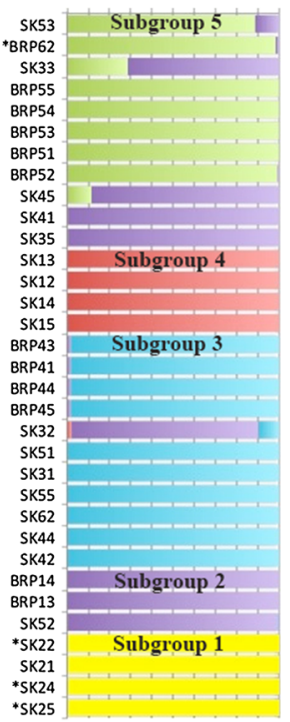

४Fig. 2 Structure analysis of 91 D. spicata (L.) Beauv. genotypes based on 10 simple sequence repeat (SSR) markers. A Separation of D. spicata genotypes into two groups by Structure v2.3. B, C Further analysis of the two main groups yielded eight sub-groups represented by different colors. Posterior probability is represented in percentages. Genotypes marked with (*) exhibited choke from Atkinsonella hypoxylon upon flowering

and $72{ }^{\circ} \mathrm{C}$ for $45 \mathrm{~s}$; and a final extension at $72{ }^{\circ} \mathrm{C}$ for 10 min. Products were analyzed on an ABI 3730xl DNA Analyzer (Applied Biosystems, Foster City, CA, USA) using $1.0 \mu \mathrm{L}$ of PCR product, $10 \mu \mathrm{L}$ of formamide (Applied Biosystems), and $0.2 \mu \mathrm{L}$ of GeneScan 500 LIZ Size Standard (Applied Biosystems). Amplified products were scored using GeneMarker version 2.6.3 (SoftGenetics, State College, PA, USA) based on the analysis parameters published by Riley et al. (2014).

\section{Germplasm characterization}

A set of 10 SSR primer pairs that amplified clear, easily distinguishable polymorphic peaks were selected for genetic diversity analysis among the 91 individual D. spicata genotypes. PCR amplification and $\mathrm{ABI}$ capillary electrophoresis conditions were the same as described for primer prescreening with the exception that the annealing temperature was based on clean amplification profiles (Table 3). Allele sizes and number of alleles per locus were determined with GeneMarker version 2.6.3. To avoid false negatives, primers that resulted in null alleles in some of the samples were tested at least twice. The polymorphism information content (PIC) for each SSR marker was calculated based on the formula published by Botstein et al. (1980). We used this parameter instead of the measure of heterozygosity $\left(P_{\text {het }}\right)$, as $P_{\text {het }}$ is utilized only for co-dominant markers (Cordeiro et al. 2003).

\section{Data analysis}

Due to polyploidy we did not make any assumptions about the genetic nature of examined alleles so each SSR allele was treated as dominant (Cordeiro et al. 2003). We have found 1-3 alleles amplified per plant for each SSR marker. The amplified allele data was converted to a binary matrix (presence/absence) for each allele and a genetic distance matrix was 
Table 2 Summary statistics for genomic simple sequence repeat (SSR) mining of D. spicata (L.) Beauv. singlet sequences

\begin{tabular}{lr}
\hline Genomic-SSR mining & No. \\
\hline Total number of sequences examined & 66,553 \\
Total size of examined sequences (bp) & $37,563,475$ \\
Total number of identified SSR markers & 3454 \\
Mono-nucleotide SSRs & 1584 \\
Di-nucleotide SSRs & 997 \\
Tri-nucleotide SSRs & 791 \\
Tetra-nucleotide SSRs & 57 \\
Penta-nucleotide SSRs & 18 \\
Hexa-nucleotide SSRs & 7 \\
Number of SSR containing sequences ${ }^{\text {a }}$ & 3219 \\
Number of sequences containing more than 1 SSR & 215 \\
Number of SSR markers present in compound formation & 138 \\
\hline
\end{tabular}

${ }^{\mathrm{a}}$ Number of SSR containing sequences: these are the singlet sequences containing various types of SSRs multilocus genotype analysis was also performed in GenAlex to identify unique combination of alleles across two or more loci.

\section{Results}

Sequencing results and microsatellite discovery

Roche-454 sequencing produced 66,553 singlet sequences (approximately $37.5 \mathrm{Mbp}$ ). These sequences were examined with the MISA algorithm, and 3454 SSR markers were identified, including 1584 mono-, 997 di-, 791 tri-, 57 tetra-, 18 penta-, and seven hexa-nucleotide repeats (Table 2). Number of SSR containing sequences were 3219; while 138 SSR markers were present in compound formation, indicating multiple SSR markers were found in certain sequences (Table 2). Out of the 63 SSR primer pairs designed with Primer-BLAST, 10 proved to be polymorphic and resulted in expected amplification profiles. From the remaining 53, 21 amplified multiple regions or an unexpected size product, 12 failed to amplify, 11 primer pairs amplified monomorphic loci, and 9 amplified stutter peaks. We spot sequenced some of the amplified products and they aligned with the original Roche 454 sequence reads (data not shown).

Germplasm characterization

The 10 SSR markers showing clear amplification products and a high degree of polymorphism were each of the 23 locations as a population. Finally, 


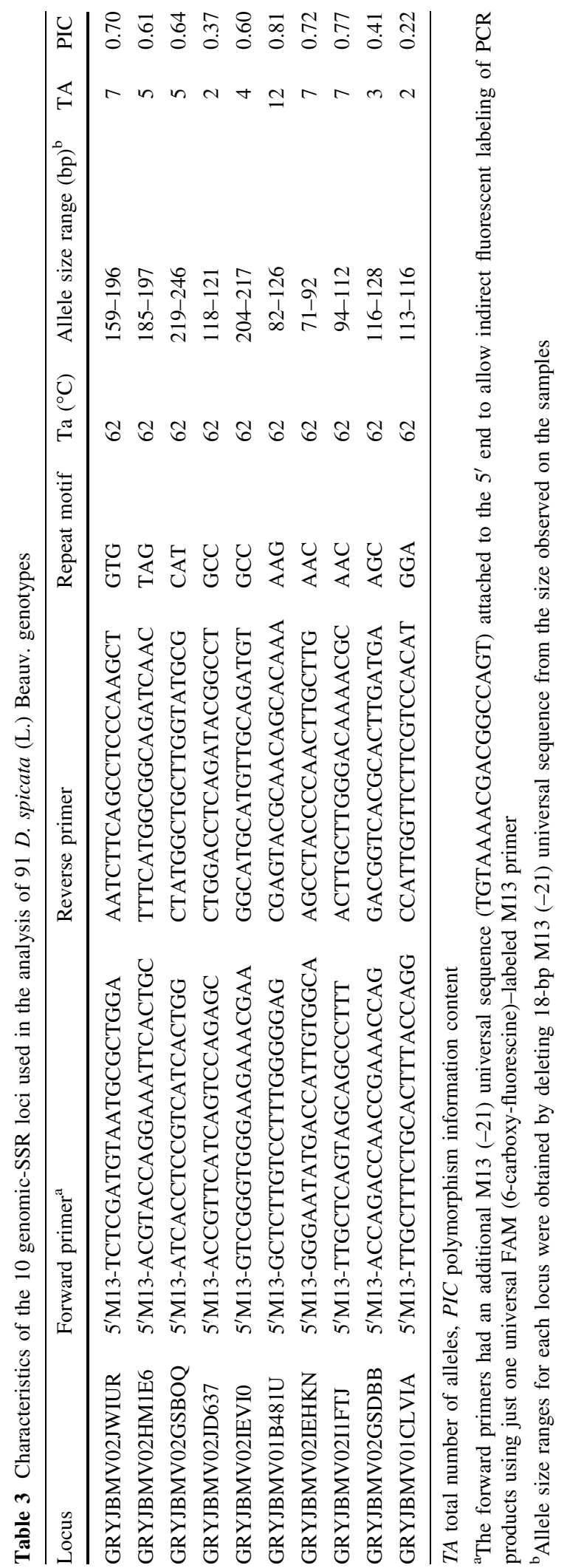


Table 4 Analysis of molecular variance (AMOVA) showing the partitioning of genetic variation within and between the populations of D. spicata (L.) Beauv. genotypes

\begin{tabular}{|c|c|c|c|c|c|c|c|}
\hline Source of variation & Df & SS & MS & Est. var. & $\%$ & PhiPT & $p^{\mathrm{a}}$ \\
\hline Among populations & 22 & 371.175 & 16.872 & 3.304 & 46 & $0.465^{*}$ & $>0.001$ \\
\hline Within populations & 68 & 258.583 & 3.803 & 3.803 & 54 & $0.541^{*}$ & $>0.001$ \\
\hline Total & 90 & 629.758 & & 7.107 & 100 & & \\
\hline
\end{tabular}

$d f$ degree of freedom; $S S$ sum of squares; $M S$ mean squares; Est. var. estimate of variance; \% percentage of total variation

*Not significant at the 0.001 probability level

${ }^{\mathrm{a}} p$ value is based on 999 permutations
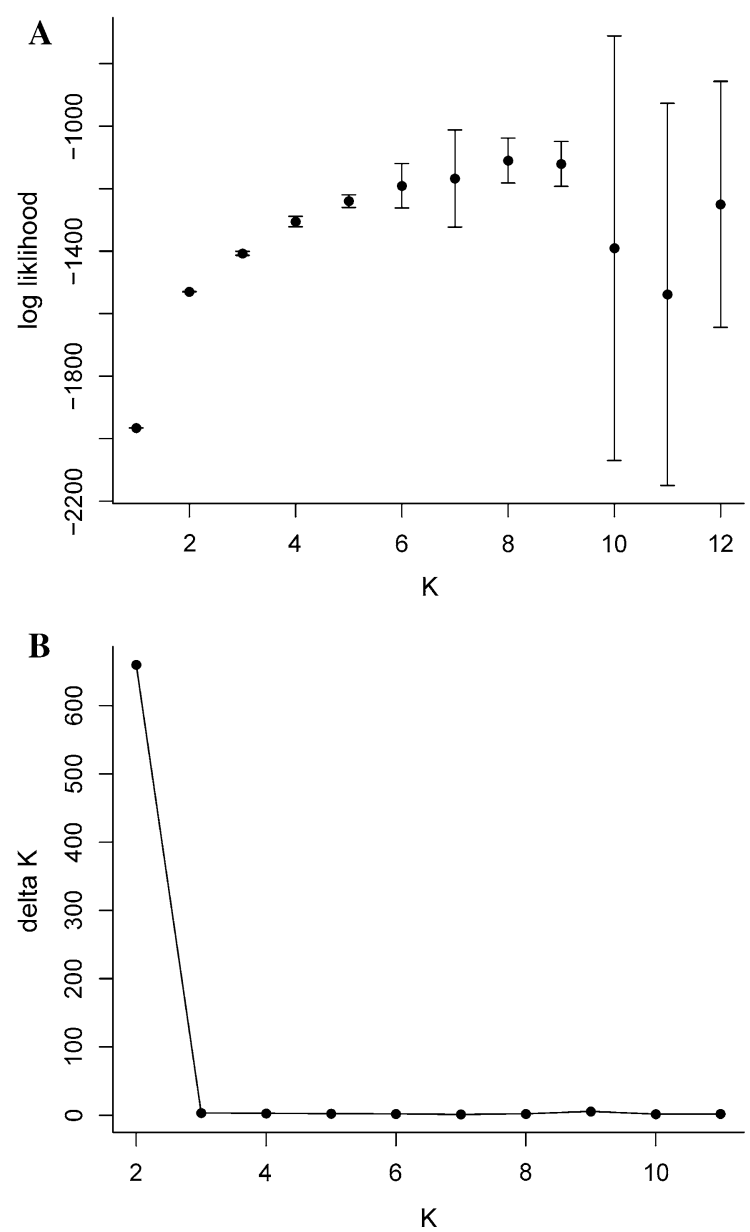

Fig. 3 Description of the two steps for the graphical method allowing detection of the true number of groups $K^{*}$. A Absolute values of the second order rate of change of the likelihood distribution (mean $\pm \mathrm{SD}$ ) calculated according to the formula: $\left|L^{\prime \prime}(K)\right|=\left|L^{\prime}(K+1)-L^{\prime}(K)\right|$. B $\quad \Delta K \quad$ calculated as $\Delta K=m\left|L^{\prime \prime}(K)\right| / s[L(K)]$. The modal value of this distribution is the true $K(*)$ or the uppermost level of structure, here two clusters selected for further analysis on the germplasm collection. They amplified 54 alleles ranging in size from 71 to $246 \mathrm{bp}$ (Table 3). Minimum and maximum number of alleles per locus were two and 12, respectively, with an average of 5.4 (Table 3). PIC values (Table 3), ranged between 0.22 and 0.81 indicating the usefulness of these markers in determining polymorphisms among the D. spicata genotypes.

Genetic similarity and population structure

Analysis of Molecular Variance (AMOVA) based on PhiPT values indicated that genetic diversity was apportioned among (46\%) and within populations $(54 \%)$, and the estimate of variance was 3.304 and 3.803 , respectively (Table 4). In addition, multilocus genotype analysis identified 14 multilocus genotype groups (Fig. 1). A dendrogram was generated using the Jaccard's genetic distance and two major groups were identified supported by 96 and $94 \%$ bootstrap, respectively (Fig. 1). Group 1 contained a majority of BRP (Blue Ridge Parkway) and SK (Skyline Drive) plants; while Group 2 contained the plants collected from the U.S. National Arboretum, Washington D.C. (EGMDT, EGMTH, EGSTR, EGMTH etc.), Klees Mill Road, Carroll County, MD (KM), Crossroads Cemetery, Carroll County, MD (CR), White House, Beltsville, MD (WH), Beltsville Agricultural Research Center, Beltsville, MD (B05), and George Washington and Jefferson National Forest Location, Hollins, VA (GW) (Fig. 1). Structure analysis of the 91 D. spicata genotypes using a model-based approach (Pritchard et al. 2000) provided evidence of population structure. Utilizing the $\Delta K$ method (Evanno et al. 2005), it was determined that $K=2$ best described the data (Figs. 2A, 3). These groups 
matched well with the UPGMA dendrogram. Further analysis of the two main groups yielded eight subgroups represented by different colors (Fig. 2B, C).

\section{Discussion}

Danthonia spicata is a native grass species often found growing in low-input turf areas on the east coast of the U.S. Much of the research concerning the reproductive biology of $D$. spicata was conducted over 30 years ago. Modern molecular techniques provide an opportunity to greatly improve the current understanding of D. spicata's unusual reproductive biology. D. spicata exhibits both axial fully cleistogamous seed heads and terminal flower heads that rarely exhibit any signs of allogamy. Both axial and terminal flower heads have very small underdeveloped anthers that produce no detectable pollen yet seed set is near $100 \%$. The literature relative to the reproductive biology of $D$. spicata is confusing and best summarized by Darbyshire and Cayouette (1989).

The most striking finding from this diversity assessment is that there are 14 multilocus genotype groups containing 39 genotypes. This is strong evidence in support of clonal reproduction in $D$. spicata. The likelihood of this number of identical genotypes existing at 10 genomic SSR loci with 54 putative alleles, through sexual reproduction is extremely small. The UPGMA dendrogram and Structure analysis were dominated by clonal groupings that exhibit variation possibly arising through mutation or migration rather than crossing and selection. Two alleles were found in only a single plant in the study and in another case an allele was found only in all four samples from a single location that is suggestive of mutations arising and then being spread through clonal reproduction. Overall it was difficult to identify polymorphic loci in D. spicata; efforts to identify variation through gel based assays were ineffective and only by focusing on tri-nucleotide SSR markers with the highest numbers of repeats and using sequencer based scoring was it possible to identify reliable polymorphism. A lack of polymorphism in D. spicata was also reported for isozyme markers by Clay and Antonovics (1985a). These findings do not support previously reported outcrossing levels based on heritability estimates of morphological variation by Clay and Antonovics (1985b). Our data and observations of anther development also support asexual reproduction through seed. Other forms of asexual reproduction are unlikely as $D$. spicata does not form rhizomes or stolons and is well adapted to spread through seed dispersal mechanisms. These findings are in support of the suggestion by Philipson and Christey (1985) that apomixis should be considered as a reproductive mechanism in D. spicata and are not supportive of the suggestion by Cheplick and Clay (1989) that D. spicata is an example of a species with both outcrossing and obligate selffertility operating at the same time. Weatherwax (1928) documented that D. spicata does not exhibit large extruded anthers or have lodicule characteristics that would be indicative of successful outcrossing. These observations were further documented by Philipson (1986) and are also supported by personal observations of the plant material collected in this study. Anther development issues support the hypothesis that D. spicata may be an example of an autonomous apomict (Philipson and Connor 1984). Analysis of Molecular Variance (AMOVA) of the data exhibited an approximately equal division of variation within and between populations. These results do not support a predominantly selfing or outcrossing reproductive strategy; as selfing species generally maintain diversity between populations while outcrossing species maintain variation within populations.

The fungal epiphyte Atkinsonella hypoxylon and its association with $D$. spicata has been reported numerous times with the implication that this association may have been an evolutionary force leading to the development of axial cleistogomous seed heads (Clay 1984). Plants infected with A. hypoxylon generally exhibit a fungal sclerotium, or "choke," that is generated at the initiation of host plant flowering and results in abortion of all but a few infected cleistogamous seeds at the base of much-reduced reproductive tiller (McCormick et al. 2001). However, only 7 out of the 91 samples in this study exhibited choke from $A$. hypoxylon upon flowering, and this level of association would not suggest that "choke" is a strong evolutionary force in D. spicata.

\section{Conclusions}

The SSR markers in this report are the first polymorphic nuclear markers available for D. spicata and 
suggest that asexual reproduction mechanisms be further explored through progeny testing.

Acknowledgements Research presented in this article was supported in part by funds from the Floral and Nursery Research Initiative administered through the United States Department of Agriculture, Agricultural Research Service (USDA-ARS). The mention of trade names or commercial products in this article is solely for the purpose of providing specific information and does not imply recommendations or endorsement by the USDA.

\section{Compliance with ethical standards}

Conflict of interest The authors declare that they have no conflict of interest.

\section{References}

Botstein D, White RL, Skolnick M, Davis RW (1980) Construction of a genetic linkage map in man using restriction fragment length polymorphisms. Am J Hum Genet 32:314-331

Chai B, Sticklen MB (1998) Applications of biotechnology in turfgrass genetic improvement. Crop Sci 38:1320-1338. https://doi.org/10.2135/cropsci1998. 0011183X003800050031x

Cheplick GP, Clay K (1989) Convergent evolution of cleistogamy and seed heteromorphism in two perennial grasses. Evol Trends Plants 3:127-136

Cidade FW, Dall'Agnol M, Bered F, Souza-Chies T (2008) Genetic diversity of the complex Paspalum notatum Flügge (Paniceae: Panicoideae). Genet Resour Crop Evol 55:235-246. https://doi.org/10.1007/s10722-007-9231-8

Cidade FW, Vigna BBZ, de Souza FHD, Valls JFM, Dall' Agnol M, Zucchi MI, de Souza-Chies TT, Souza AP (2013) Genetic variation in polyploid forage grass: assessing the molecular genetic variability in the Paspalum genus. BMC Genet 14:50. https://doi.org/10.1186/1471-2156-14-50

Clay K (1982) Environmental and genetic determinants of cleistogamy in a natural population of the grass Danthonia spicata. Evolution 36:734-741

Clay K (1984) The effect of the fungus Atkinsonella hypoxylon (Clavicipitaceae) on the reproductive system and demography of the grass Danthonia spicata. New Phytol 98:165-175

Clay K, Antonovics J (1985a) Demographic genetics of the grass Danthonia spicata: success of progeny from chasmogamous and cleistogamous flowers. Evolution 39:205-210

Clay K, Antonovics J (1985b) Quantitative variation of progeny from chasmogamous and cleistogamous flowers in the grass Danthonia spicata. Evolution 39:335-348

Coello Coello CA, Cortés NC (2005) Solving multiobjective optimization problems using an artificial immune system. Genet Program Evolvable Mach 6:163-190. https://doi. org/10.1007/s10710-005-6164-x
Cordeiro GM, Pan Y, Henry RJ (2003) Sugarcane microsatellites for the assessment of genetic diversity in sugarcane germplasm. Plant Sci 165:181-189

Darbyshire SJ (2003) Danthonia DC. In: Flora of North America and North of Mexico, vol 25 (eds) Flora of North America Editorial Committee. Oxford University Press. New York, pp 301-306

Darbyshire SJ, Cayouette J (1989) The biology of Canadian weeds, 92. Danthonia spicata (L.) Beauv. in Roem. ex Schult. Can J Plant Sci 69:1217-1233

Evanno G, Regnaut S, Goudet J (2005) Detecting the number of clusters of individuals using the software STRUCTURE: a simulation study. Mol Ecol 14:2611-2620. https://doi.org/ 10.1111/j.1365-294X.2005.02553.x

Grass Physiology Working Group (2001) Phylogeny and subfamilial classifications of the grasses (Poaceae). Ann Mo Bot Gard 88:373-457

Guo H-L, Xuan J-P, Liu J-X, Zhang Y-M, Zheng Y-Q (2012) Association of molecular markers with cold tolerance and green period in zoysiagrass (Zoysia Willd.). Breed Sci 62:320-327

Honig J, Bonos S, Meyer W (2010) Isolation and characterization of 88 polymorphic microsatellite markers in Kentucky bluegrass (Poa pratensis L.). HortScience 45:1759-1763

Joshi SP, Prabhakar K, Ranjekar PK, Gupta VS (2011) Molecular markers in plant genome analysis. http://www.iisc. ernet.in/currsci/jul25/articles15. Accessed Sept 2016

Kalia RK, Rai MK, Kalia S, Singh R, Dhawan AK (2011) Microsatellite markers: an overview of the recent progress in plants. Euphytica 177:309-334. https://doi.org/10.1007/ s10681-010-0286-9

Kubik C, Honig J, Meyer WA, Bonos SA (2009) Genetic diversity of creeping bentgrass cultivars using SSR markers. Int Turfgrass Soc Res J 11:533-547

Legendre P, Legendre L (1998) Numerical ecology, 2nd edn. Elsevier Science BV, Amsterdam, p 853

Linder HP, Verboom GA (1996) Generic limits in the Rytidosperma (Danthonieae, Poaceae) complex. Telopea 6:597-627

McCormick MK, Gross KL, Smith RA (2001) Danthonia spicata (Poaceae) and Atkinsonella hypoxylon (Balansiae): environmental dependence of a symbiosis. Am J Bot 88:903-909

Peakall R, Smouse PE (2012) GenAlEx 6.5: genetic analysis in Excel. Population genetic software for teaching and research-an update. Bioinformatics (Oxford, England) 28:2537-2539. https://doi.org/10.1093/bioinformatics/bts 460

Philipson MN (1986) A re-assessment of the form of reproduction in Danthonia spicata (L.) Beauv. New Phytol 103:231-243. https://doi.org/10.1111/j.1469-8137.1986. tb00611.x

Philipson MN, Christey MC (1985) An epiphytic/endophytic fungal associate of Danthonia spicata transmitted through the embryo sac. Bot Gaz 146:70-81

Philipson MN, Connor HE (1984) Haustorial synergids in danthonioid grasses. Bot Gaz 145(1):78-82

Powell W, Machray GC, Provan J (1996) Polymorphism revealed by simple sequence repeats. Trends Plant Sci 1:215-222. https://doi.org/10.1016/1360-1385(96)868981 
Pritchard JK, Stephens M, Donnelly P (2000) Inference of population structure using multilocus genotype data. Genetics 155:945-959

Riley M, Sheng C, Liu J (2014) Microsatellite analysis with linked pedigree tool. http://www.softgenetics.com/PDF/ GM_Microsatellite_AppNote_2014.pdf. Accessed May 2016

Schuelke M (2000) An economic method for the fluorescent labeling of PCR fragments. Nature Biotechnol 18:233-234

Suzuki R, Shimodaira H (2015) Pvclust: hierarchical clustering with $p$ values via multiscale bootstrap resampling. $\mathrm{R}$ package version 2.0-0. http://CRAN.R-project.org/ package $=$ pvclust

Tamaki H, Wright CL, Li X, Lin Q, Hwang C, Wang S, Thimmapuram J, Kamagata Y, Liu W-T (2011) Analysis of 16S rRNA amplicon sequencing options on the Roche/454 next-generation Titanium sequencing platform. PLoS ONE 6:e25263. https://doi.org/10.1371/journal.pone.0025263

Thammina C, Olsen RT, Malapi-Wight M, Crouch JA, Pooler MR (2014) Development of polymorphic genic-SSR markers by cDNA library sequencing in boxwood, Buxus spp. (Buxaceae). Appl Plant Sci 2:e1400095. https://doi. org/10.3732/apps.1400095

Warnke S (2010) There's a new native low-input turfgrass option in town. http://archive.lib.msu.edu/tic/golfd/article/ 2010may49. Accessed Sept 2016

Weatherwax P (1928) Cleistogamy in two species of Danthonia. Publication no. 31 of the Waterman Institute for Scientific Research, Indiana University. Bot Gaz 85:104-109

Wu YQ, Taliaferro CM, Bai GH, Martin DL, Anderson JA, Anderson MP, Edwards RM (2006) Genetic analysis of Chinese Cynodon accessions by flow cytometry and AFLP markers. Crop Sci 46:917-926. https://doi.org/10.2135/ cropsci2005.08.0256

Ye J, Coulouris G, Zaretskaya I, Cutcutache I, Rozen S, Madden TL (2012) Primer-BLAST: a tool to design target-specific primers for polymerase chain reaction. BMC Bioinform 13:134. https://doi.org/10.1186/1471-2105-13-134 